\title{
MANAGER'S ROLE AND SKILLS \\ IN DESIGN MANAGEMENT \\ IN THE ORGANIZATION
}

\author{
Magdalena Klimczuk-Kochańska \\ University of Warsaw, Faculty of Management, Warsaw, Poland \\ e-mail: mklimczuk@wz.uw.edu.pl \\ University of Warsaw, Faculty of Management, Warsaw, Poland
}

\begin{abstract}
Purpose: The purpose of this paper is to present the undertaken literature review regarding the extent to which analysis and research on design management and design managerial skills have been carried out so far.
\end{abstract}

Methodology/approach: A literature review is presented along with several types of management as possible solutions to restraining the problem of introducing design to the organization as a way to develop the organization's innovative activities.

Findings: The paper presents design as a type of organization activity important from the point of view of innovation and competitiveness of enterprises. The essence of design and its role in innovative processes are described. Design management and the role of design managers were characterized. Managerial skills necessary for the adequate implementation of design activities in the organization were also shown. The above considerations were based on the literature review.

Implications/limitations either for future research, for practice, or for society: Most of the studies are based on research conducted years ago. The topic of design management returns in business practice, but there is little research on this topic in modern enterprises. Especially rarely, these topics apply to small and medium-sized enterprises that could benefit a lot from the implementation of design management.

Originality/value of the paper: The paper begins with an overview of the role of the design in the innovation processes and then moves on to the implementation of design management. The author then proposes several categories of the managerial skills required for design activities in the organizations and presents their importance for the innovation activities in the organization.

Keywords: design management, managerial skills, design, design-driven innovation

Paper type: Conceptual paper

\section{Introduction}

Design-based innovation should play an increasingly significant role in the development strategies of companies. Confirmation of this statement can be already found in the literature on the subject from the 1980s and 1990s. However, 
MANAGER'S ROLE AND SKILLS IN DESIGN MANAGEMENT

Magdalena Klimczuk-Kochańska there is often a lack of or insufficient knowledge about the potential advantages of using design in organizations. In addition, an important barrier in this respect seems to be the fact that such innovations require the enterprise to have an ability to understand, predict and influence the emergence of new meanings of innovative products. This may require cooperation with a large group of external entities, including, for example, designers, artists, programmers, and suppliers. Therefore, design management and design-based innovation require managing relationships with these people and organizations to gain access to knowledge and its dissemination. As a consequence, the manager's challenge is to perform several roles simultaneously. The special role is to be a "translator" of the project concept as well as its meanings and values to other members of the organization. The interdisciplinarity of design also requires considerable knowledge, because, in addition to understanding design, it is necessary to have knowledge about the market or a given technology. It is also necessary to have a thorough understanding of the aspects of cooperation and communication with external entities, as well as very good knowledge of the procedures that are used in a given enterprise.

\section{The essence of design and its role in innovation processes}

In the literature, one can find many definitions of design, understood in this study also as project work and planning. For example, V. Caldecote (1979) describes the design as a process of transforming an idea into information from which a new product can be made. Design is, therefore, an activity in which ideas and needs acquire physical form, initially as a concept of solution and then as a specific configuration of elements, materials, and components. Designing is about visualizing previously accepted concepts, plans or ideas. It covers a wide range of activities, as the design is considered to include sketches, models, and other forms of presentation of ideas and intentions. Thanks to designing, it is possible to create something that did not exist so far or did not exist in a given form before (Walsh, 1996).

However, as early as the end of the 1950s, it was recognized that industrial design could be used in other areas than just product styling (Bohemia, 2002). Nowadays, such an approach to design is common, as it is recognized that design should not be seen only as an activity related to the creation of a coating or a product form. The design has become an essential element in the creation of industrial products, processes, and services across the economy (Woodham, 2010). The act of design requires a combination of logical and intuitive thought. The change of perspective on design makes it find its place not only in sectors such as graphics, architecture, fashion, and textiles but also in the design of industrial products and processes taking place, for example, in the pharmaceutical or information and communications technology (ICT) industries (Walsh, 1996). 
How design is perceived by various people and fields depends on what purpose they assign to it. The designers themselves can see their work in terms of creativity, problem-solving or art. Marketing managers will see the work of the designers employed by their company as aimed at differentiating their products from other goods. Such activity is aimed at increasing the attractiveness of the offer and at least limiting the activity of the competition. This type of activity can be perceived even more differently by consumers. They see design effects as new styles and fashions. They notice improvements in products that make them easier to use, or they may notice that the products are, for example, less energy-intensive or more durable. Thus, from the point of view of consumers and users, design shapes ideas so that the offer becomes more practical and attractive.

The project consists of both the aesthetic appearance of the product, functionality, sense of the product and its meaning. R. Verganti (2011) indicates that the concept of "meaning" is to serve as a psychological and cultural reason for choosing and using a product. Design is intended to influence both on the individual motivation of consumers and users with psychological and emotional significance of the product and on social motivation through symbolic and cultural significance. Therefore, the designer involved in the design process delivers a product that represents a unique combination of technology and market and is relevant to customers (Dell'Era and Verganti, 2010). The result is the so-called "design driven innovation".

Every innovation, from the most radical to the incremental, requires design input. As both literature and business practice show, the design is seen not only as product development work but can also be understood as the core of new product and service development processes. It is, therefore, part, or even the core, of innovation development processes. A new object is imagined, developed, and shaped in a prototype form (OECD, 2015). Designing is not only identified with research and development (R\&D) activities. Each basic idea or invention can generate a wide range of possible design configurations and subsequent modifications. This is possible thanks to the use of design, which is very often based on previous inventions and innovations. This means that design often does not require any technical changes but can result in a product characterized by a different form, style, design, or cover. Such an activity is a kind of "fashion design," which A. Piatier described as "non-innovative novelties" (Piatier, 1984, a quote from Walsh et al., 1993). This means that design often involves integrating new components, materials, or production methods into an existing product. Enterprises implementing innovation management consider design to be a crucial element of organizational change. This can be done, for example, by building new organizational capabilities in the process of new product development (NPD) or by using the so-called "design thinking", which is a method of working on the development of new products and services (Junginger, 2008).
MANAGER'S ROLE AND SKILLS IN DESIGN MANAGEMENT

Magdalena Klimczuk-Kochańska 
MANAGER'S ROLE AND SKILLS IN DESIGN MANAGEMENT

Magdalena Klimczuk-Kochańska
The above characteristics of design indicate its potential importance for enterprises, but it is still not an area that is popular and well developed in many enterprises. Design understood as part of innovation development processes does not exist in most companies. In some cases, designers are employed as part of the organization's staff (Acklin, 2010). Companies such as e.g., 3M, Apple, IBM, IKEA, Nike, Unilever, Pepsi, Procter \& Gamble, are named as design-led organizations.

The fact that many organizations do not have a clear innovation strategy that is developed and implemented is also not conducive to innovation and design activities. The potential benefits of such activities are still rarely recognized. At the same time, small and medium-sized enterprises very often assume that not only do they have no money to carry out this kind of activity, but what is still important, they lack knowledge about design and the way of performing this function within the organization.

\section{The specificity of design management}

In 1965 M. Farr (1965) proposed the first definition of design management. He understood this management as defining the design problem, finding the most suitable designer, and enabling him/her to solve it on time and within the given budget. P. Gorb and A. Dumas (1987) considered project management to be a series of organizational and management activities or practices that are required for the design process. According to the Design Management Institute (DMI) based in Boston, MA, design management is the business side of design. This means that such management is focusing on combining design, innovation, technology, management, and customer expectations. All these activities are undertaken in order to ensure a competitive advantage with regard to economic, socio-cultural, and environmental conditions. Project management can also be defined as activities or organizational and management skills that optimize the design process.

The implementation of design management in an organization can be undertaken at various levels. The approach developed by the Danish Design Centre (DDC), described as the "design ladder," reflects this well. This ladder consists of several levels, which show the increasing degree of involvement of the organization in design activities. These are: (1) lack of design - design is not included in the organization's activities at all; (2) design as a style - design serves as an aesthetic addition (mainly to material products); (3) design as a process - design is integrated with development processes, and (4) design as a strategy design is treated as a key activity supporting the creation of innovation.

Moreover, C. Acklin and A. Fust (2014) proposed the division of projects according to the criterion of awareness of the usefulness of design and design management in achieving the company's objectives, into four types of project 
management. These are: (1) simple design management; (2) integrated design management; (3) dynamic design management; and (4) entrepreneurial design management. Simple design management characterizes companies that are interested in more effective process management and apply this type of management, mainly in the development of new products or services. Using this kind of project management allows companies to avoid the immeasurability of their products by managing new product projects more effectively and efficiently. This type of management is usually carried out by marketing department employees and managers responsible for the development of new products. The key role of design in this approach is to create improved products as well as work on the appearance of these goods.

The second type, integrated project management, is also referred to as continuous project management. It involves the coordination and implementation of design in all departments, functions, and processes necessary to create consistent customer service and contributing to positioning the company in the market. It means managing project processes and their results. This mode of project management is called integrated because there is an extensive adaptation, communication, learning between often contradictory parts of the organization. It involves the integration of design at every level of the organization, through the participation in the project management. The reference of this type of project management to various "contact points" between organizational functions promotes the integration of different processes that affect the satisfaction of the end-user of the product. Responsibility for integrated project management lies with the project managers.

Dynamic design management aims at a sustainable competitive advantage for the organization, which it can gain through the mediation between the internal world of the organization and its external environment. Such extensive activities are related to strategic, innovation, process, and change management. Therefore, a wide range of knowledge from various levels of organization and design expertise is required. Moreover, it is necessary to involve leaders and managers in design issues as well as senior management.

The importance of dynamic design management seems particularly important in the context described by D.J. Teece et al. (1997) as "stickiness of resources" which, at least for a short period, can to some extent "glue" companies to the resources and competencies they possess. This means that design as such does not offer a solution to upcoming changes and threats from the environment. Dynamic design management is necessary to encourage the absorption and use of new knowledge by the organization and to avoid the "stickiness-trap." This problem is also pointed out by authors such as C.M. Christensen (2000), who notes that successful companies may even face the innovator's dilemma of not wanting to risk their own business through innovations that disrupt the existing order in the
MANAGER'S ROLE AND SKILLS IN DESIGN MANAGEMENT

Magdalena Klimczuk-Kochańska 
MANAGER'S ROLE AND SKILLS IN DESIGN MANAGEMENT

Magdalena Klimczuk-Kochańska organization. The ability to continuously acquire new knowledge is a dynamic ability, associated with the creation and use of knowledge, which increases the ability of the company to gain and maintain a competitive advantage. In this context, E. Danneels (2002) even states that there is a need to move away from the notion of a portfolio of products to the notion of a portfolio of competencies which allows for the development of new products.

As the fourth type of project management, C. Acklin and A. Fust (2014) indicate the entrepreneurial design management. The basic elements of entrepreneurship are: (1) business opportunities; (2) resources needed to seize the opportunities; and (3) an organization that matches the company's predicted future with its market environment. Depending on the positions held by the company's design managers, they will be able to influence most of the areas mentioned above. If, for example, a design manager is responsible for monitoring trends or product development, then the recognition, evaluation and use of opportunities can be the basis of his/her work.

As in the case of other disciplines, the implementation of this function in the organization operates on three levels: strategical, tactical, and operational. Project management is at a strategic level. This is where the general principles, missions and action programs are established. Processes and systems of specific business units or functions are implemented on a tactical level. At the operational level, design manifests itself in physical and tangible products, services, and experiences (Best, 2006).

The above considerations cannot be done without addressing the critical issue of the literature's approach to design in the context of design management and leadership. There are authors who claim that the concept of design management was rather used in the past, but now it is more appropriate to use the term "design leadership." It allows describing a more strategic level related to the vision of using the project in the organization to achieve corporate goals (Borja de Mozota, 2003). Similarly, J.P. Kotter (1996) distinguishes between leadership and management. He describes leaders as people who can create and communicate visions and strategies. Furthermore, he claims that management is mainly about the status quo, and leadership is mainly about change (Kotter, 1996). In a business environment, the relationship between management and leadership is crucial. Without this relation, shaping innovation and maintaining growth is difficult.

Design leadership is needed to know where the company is going, while design management is needed to know how to get there (Acklin and Fust, 2014). Project management is considered to be reactive as it mainly manages the resources, time, people, and money needed for design-related activities within the company. Leadership in design is considered to be proactive. Because it contributes to establishing the program of the company using the design to gain 
a competitive advantage and to predict the future. A. Topalian (1990) argues that design leadership is one of the most powerful ways to generate new ideas.

Leadership in innovation does not mean being a multidisciplinary expert. However, innovation leadership requires listening to what other professionals contribute because innovation does not take place in isolation (Gaynor, 2002). Leadership determines what the future should look like, adapts people to this vision and inspires them to act despite the obstacles (Kotter, 1996). This affects the translation of strategy into the design in the strategic activities of enterprises, but it is essential that managers responsible for design activities have the skills necessary to carry out these functions.

\section{Design business features and managerial skills required for design activities}

As mentioned earlier, the design is essentially the application of human creativity to a specific purpose. It is important to select and configure the elements, materials and components that give unique product features such as appearance, performance, ease of use or production methods (Roy and Riedel, 1997). It is necessary to take into account all the functional, operational, production and communication requirements of the products. This means that a designer's work not only includes creative effort, but also a set of numerous technical, strategic, and market-related activities.

As V. Walsh et al. (1993), indicate design activity has four main characteristics. They can be described as " 4 C's of project management". These are:

1. Creativity: design means creating something that did not exist before (from a variant of an existing project to an entirely new concept).

2. Complexity: design requires a decision that takes into account a large number of parameters and variables (from overall configuration and performance to, among others, components, materials, appearance, and production method).

3. Compromise: design requires balancing many, sometimes conflicting requirements (such as performance and cost; appearance and ease of use; materials and durability).

4. Choice: design requires the choice of many possible solutions to a problem at all levels, from the basic concept to the smallest details in terms of color or form of the product.

The approach is in line with the opinion of A. Linden (2017). As, among others, Director of Product Design at Facebook, Head of Design at Asana and Design Director at Intuit, based on the professional experience, she presented dynamic roles of the design manager. In the discovery phase manager role is "salesperson". They present a direct report about an exciting new project and why the project matters. Once employees are on board, then re role of
MANAGER'S ROLE AND SKILLS IN DESIGN MANAGEMENT

Magdalena Klimczuk-Kochańska 
MANAGER'S ROLE AND SKILLS IN DESIGN MANAGEMENT

Magdalena Klimczuk-Kochańska a design manager is to be an "active partner" who's helping them define goals and constraints. Design phase means that the manager has to "stepping back". Employees get clear on goals, gains confidence, and starts to generate ideas. On the stage of the development thought partner for other employees is needed. Developers from the company enter into the design process and add new insights into the project. The manager should stay at arm's length and be a "thought partner" for high-level questions. At the end of the project in the deployment phase, the manager's role is to be "recognizer". It means especially to recognize the employee for their accomplishments. Design manager has to look at the finished product - the before and after -and help designers see why their outcome of previous work is better than they think, because of their selfcriticism. (Linden, 2017).

The work of designers is specific and, as the literature indicates, they should be an integral part of the design team from the very beginning. The designers' experience and their ability to visualize and combine project ideas to everyday life can often facilitate common understanding during the design process among team members. This ensures the effective coordination of many crucial product aspects. Designers and design managers should be responsible for the overall perception of product quality, as they are able to see both the overall concept and each detail (Bohemia, 2002).

Unfortunately, often the organizational culture of companies with little or no design know-how is goal-oriented and conducive to decision making with a strong emphasis on effectiveness and efficiency. In these organizations, the design seems to be just a pleasant addition to their business. It is not regarded as an obligatory factor in the process of company development.

A different approach to designers' work is shown by V. Walsh (1996). This scholar describes the role of the designer as a "gatekeeper." This means that the designer should have access to all specialist functions within the company, such as research and development, marketing, manufacturing, finance, material testing and even strategic management and corporate planning. It also requires access to many areas of the company's external operations, which are related to following trends in fashion and design, and mean the need to use new materials, machines and production processes. This approach allows the designer to respond to consumer behavior. Access allows designers to collect the necessary information for input in the design process.

However, it is often difficult for designers to enter these roles. Even if an organization employs people in design positions, they may lack design management skills. As a result, many designers discover that there is a "glass door" between them and the rest of the organization. They involve the difficulty, or even impossibility, of relating to the business context and communicating effectively with other disciplines and senior management of the organization. 
An example is a situation when, in 1996, Tesco's packaging design manager Kevin Vyse quit. He found a problem related to how the supermarket giant tackles packaging. He was troubled especially by the attitude of Tesco's trading directors towards packaging design. Lack of proper cooperation and understanding of design policy did not allow him to continue working at Tesco (Design Week).

Hence, continuous professional development is important, which is emphasized by the European Design Leadership Board (EDLB). It is intended to improve their ability to communicate effectively with senior management and multidisciplinary teams within and outside companies. EDLB also points out that a lack of project management skills is a significant barrier to the adoption and integration of design in European companies (Thomson and Koskinen, 2012). This is crucial if we are to assume that designers and their motivation to work are an important contribution to innovation processes in an organization.

It is design management that seems to be a particularly crucial element in the activity of an organization that decides to carry out more or less design activities. R. Chiva and J. Alegre (2007) conducted a study on the relationship between design management skills and organization of project functions. Citing M. Bruce and B. Morris (1994), R. Chiva and J. Alegre considered three various ways of organizing this function: (1) solely in-house, (2) solely outsourcing, and (3) a combination of the previous two solutions. Studies show that the highest level of design management skills has been achieved in an internal approach. In the external approach to the design function, the lowest level of design management skills is achieved. Therefore, an internal approach seems to be the best option to improve project management. The authors of the research also showed that companies using an external and mixed approach to project management obtain product designs primarily from their suppliers. As a result, when suppliers do not develop long-term relationships and are not as committed, responsible or enthusiastic about their clients' projects as internal design consultants can be, the results of their work are not as good as the internal design activities of the organization. Companies that consider design as a competitive resource and develop it are improving their project management skills (Chiva and Alegre, 2007). Entities that use their design of products by internal companies emphasize the importance of the design department and R\&D department, which bear the greatest responsibility for making design decisions. The design department is also usually a technology department. On the other hand, a mixed approach and the use of design services offered by external companies emphasize the importance of the marketing department or managers of other departments in making design decisions.

Hiring an employee as a project manager has a significant impact on attitudes and practices in the company. Surveys of companies carrying out design activities show that (1) design managers should have authority in the organization and (2)
MANAGER'S ROLE AND SKILLS IN DESIGN MANAGEMENT

Magdalena KlimczukKochańska 
MANAGER'S ROLE AND SKILLS IN DESIGN MANAGEMENT

Magdalena Klimczuk-Kochańska there is a high level of responsibility for design. In addition, if a project manager is employed in the company, then the design is more likely to have a similar organizational structure to other projects within the organization and be considered as not requiring central control. At the same time, companies with employed project managers perceive the design function as influencing the company's policy in terms of employment, finance, and project development. Such companies use design as equivalent to other activities of the organization (Dumas and Whitfield, 1989).

The Polish company Flowair, which deals with heating and ventilation products is an example of this approach. The company manufactures heaters, curtains, ventilation units. Design management and designer are the company's "driving wheel". The design activities in this company do not focus only on the aesthetics of the devices. Critical is ergonomics and functionality of the solutions, and on technology that is tailored to the needs of users. The designer of the company became its "good spirit". Other company's success factor, the owner indicates the creation of an interdisciplinary design team - in addition to designers, and the R\&D department, product managers and marketing department employees are also involved in working on new products. Together, they form a team that implements an innovative approach not only in the visual sphere of products but also in technology and communication area. Involvement in design activities has resulted in many prestigious awards: among others, the two most prestigious awards in the world of industrial design: Reddot design award and iF product design award. (Rutkowski, 2015; Rutkowski, 2016)

The development of project management skills plays a significant role in undertaking project activities in the company. There are many references in the literature to the ideas of P. Dickson et al. (1995) concerning types of project management skills in an organization. He proposed the following types of skills: (1) basic, (2) specialized, (3) involving of others, (4) organizational change, and (5) innovation (Fernández Mesa et al., 2013).

The basic skills are to manage the basic activities of the design process in order to have a high quality design, manufacturability and low-cost products as well as to ensure that new products are designed and marketed quickly. All these skills are considered essential for the design process. R. Roy and J.C. Riedel (1997) stated that commercially successful product development projects focus on product performance and quality. In selected cases, technical or design innovations are important. At the same time, these authors paid more attention to real product improvements and not only to cost reductions.

The second group covers the specialist skills that relate to managing some of the specialist activities required in the product design process. These skills include costing a new product, the ability to effectively use the latest computer design tools, testing the productivity of new products during the design process, and 
finding people with excellent design skills. In other words, the work of a designer requires a set of traditional design skills in the fields of aesthetics, visualization, and technical skills (Perks et al., 2005). Therefore, in design management, it is important to choose the right criteria for selecting employees to carry out project functions in the organization.

Involving others means including customers and suppliers in the design process to get new product ideas. This allows for better execution of design processes and the acquisition of new product ideas from customers. P. Gorb and A. Dumas (1987) also underline the importance of design interaction with other entities and consider that the product design process requires the presence and active involvement of different actors such as customers and suppliers. Also, V. Walsh (2000) points out that project management plays an important role here, which must ensure dialogue between all persons with a significant interest in the use of the project, including the final customer.

The ability to manage organizational change plays a particularly key role in project activities. According to P. Dickson et al. (1995), these skills involve changing traditional ways of doing things, combining distinct functions within the company, and replacing sequential work with co-design. In contrast, other authors (Kotler and Rath, 1984) underline the importance of communicating with marketing, sales, engineering or research departments in order to stimulate dialogue with other areas surrounding product development. Similarly, H. Perks et al. (2005) emphasizes that the project is part of a multifunctional team. They stress that the designers' activities are dominated by communicative behaviors that require personal, communicative and teamwork development.

Not without reason, as the fifth type of project management skill, P. Dickson et al. (1995) gives innovative skills. After all, it is the designers and project managers who are expected to focus especially on thinking about innovation. As part of their tasks, they should set priorities and strategies for the organization. In addition, they control their resources, set the tone for most discussions and activities in organizations, and filter ideas and information from external sources. Therefore, innovation skills mean the ability to manage innovation through awareness and knowledge of competitive innovation and imitation as a source of radically new design ideas (Fernández-Mesa et al., 2013). The ability to manage innovations takes place by quickly becoming aware of innovations and imitations of the competition and finding new design ideas, not just imitations. Similarly, P. Kotler and G.A. Rath (1984) emphasize the importance of managerial support in the field of creative design. They assume that one of the most important aspects of project management is the in-depth knowledge of the company and its competitors as a contribution to the innovation process. They also find it important to stimulate creativity. They argue that the designers' deep knowledge and diversity of backgrounds, interdisciplinary teams, and their involvement in the preliminary
MANAGER'S ROLE AND SKILLS IN DESIGN MANAGEMENT

Magdalena Klimczuk-Kochańska 
MANAGER'S ROLE AND SKILLS IN DESIGN MANAGEMENT

Magdalena Klimczuk-Kochańska stages of planning are key to formulating innovative products. Process design is seen as the main force for innovation, giving the opportunity to enter new markets and their other segments (Chiva Alegre, 2007).

The Estonian Balteco is a producer of the hydromassage baths. The company design director Aivar Habakukk has presented the task of the design director as management of the whole organization. The design director in this company is engaged in activities related to company image, product development, and in many other things, for example designing a fair booth and retail spaces both in Estonia and at its distributors' locations. Product designer work does not mean to be an artist who creates products, because developing a new product in a manufacturing company is a planned activity. The design manager has the necessity to define by the target country, sales statistics, trends in interior architecture and design and governing technologies. Product design is teamwork, and the product development team starts with and ends with a weekly product development meeting. Once a year, the company organize talks about its strategic plans (Balteco).

Design management is a complex field. It does not refer to a single design discipline, and the specific responsibilities imposed on a project manager or designer will depend, among other things, on the organization they work for, the size of that organization, the industry in which they work, their current market position and, to a large extent, their perception of the importance of design in the industry. This requires a range of competencies and skills, the possession of which is conducive to the development of project activities in the organization.

\section{Conclusion}

The innovative capacity of companies depends to a substantial extent on project management skills. Not so much stylization as giving new meanings to products and services is an important direction of business operations. Even if the company does not have its employees with the design department, it is still necessary to have the knowledge and skills to cooperate with other entities.

Successful design activity means, above all, integrating both inside and outside the organization. This activity is complex, requires creativity and compromise, as well as selecting solutions appropriate for the organization and its strategy. Therefore, professional project management has to cover many aspects related to design and project activities and requires managers to have the right skills. These concerns not only the very specificity of design, but also the involvement of other participants, organizational change management, and innovation management. Only managers suitably qualified and willing to act are able to manage design effectively. This means that it is necessary to support human resources in the organization in terms of improving their qualifications.

It seems that due to the limited literature on the subject and research related to especially small and medium sized organizations reality of conducting design 
activity by organizations, it is necessary to undertake further analyses showing the relationship between design management skills and organization. Such work can be particularly valuable on a practical level. Therefore, it should be considered as a future direction of research in relation to the topic of design management in organizations. The implications of such research for the realities of business could contribute to a better understanding of the design and its management, as well as to the more frequent introduction of at least design elements by organizations. As a result, they could foster improved cooperation, team building within companies and approaches to new problems faced by organizations.

\section{References}

Acklin, C. (2010), "Design-Driven Innovation Process Model”, Design Management Journal, Vol. 5 No. 1, pp. 50-60. DOI: 10.1111/j.1948-7177.2010.00013.x

Acklin, C., Fust, A. (2014), “Towards a dynamic mode of design management and beyond", 19 $9^{\text {th }}$ DMI: Academic Design Management Conference Design Management in an Era of Disruption London, 2-4 September 2014. DOI: 10.13140/2.1.4145.0887

Balteco, "Design Management", available at: https://balteco.com/about/design-philosophy (accessed 6 June 2020).

Best, K. (2006), Design management: managing design strategy, processes and implementation, AVA Publ., Lausanne.

Bohemia, E. (2002), "Designer as Integrator: Reality or Rhetoric?", The Design Journal, Vol. 5 No. 2, pp. 23-34. DOI: 10.2752/146069202790718549

Borja de Mozota, B. (2003), Design Management. Using design to build brand value and corporate innovation, Allworth Press, New York.

Bruce, M., Morris, B. (1994), "Managing external design professionals in the product development process", Technovation, Vol. 14 No. 9, pp. 585-599. DOI: 10.1016/0166-4972(94)90041-8

Caldecote, V. (1979), "Investment in new product development", Journal of the Royal Society of Arts, Vol. 127 No. 5279, pp. 684-699.

Chiva, R., Alegre, J. (2007), "Linking design management skills and design function organization: an empirical study of Spanish and Italian Ceramic tile producers", Technovation, Vol. 27 No. 10, pp. 616-627. DOI: 10.1016/j.technovation.2007.05.015

Christensen, C.M. (2000), The innovator's dilemma, Harper Business, New York.

Danish Design Centre (2019), "The Design Ladder: Four steps of design use”, DDC, available at: https://danskdesigncenter.dk/en/design-ladder-four-steps-design-use (accessed 13 October 2019).

Danneels, E. (2002), "The dynamics of product innovation and firm competences", Strategic Management Journal, Vol. 23 No. 12, pp. 1095-1121. DOI: 10.1002/smj.275

Dell'Era, C., Verganti, R. (2010), “Collaborative strategies in design-intensive industries: knowledge diversity and innovation", Long Range Planning, Vol. 43 No. 1, pp. 123-141. DOI: 10.1016/j.lrp.2009.10.006

Design Management Institute (2019), “What is design management?", DMI, available at: https://www.dmi.org/page/What_is_Design_Manag (accessed 15 October 2019).

Design Week, “"Frustrated' packaging manager leaves Tesco”, available at: https://www.
MANAGER'S ROLE AND SKILLS IN DESIGN MANAGEMENT

Magdalena Klimczuk-Kochańska 
MANAGER'S ROLE AND SKILLS IN DESIGN MANAGEMENT

Magdalena Klimczuk-Kochańska designweek.co.uk/issues/7-november-1996/frustrated-packaging-manager-leavestesco/ (accessed 2 June 2020).

Dickson, P., Schneider, W., Lawrence, P., Hytry, R. (1995), "Managing design in small high growth companies", Journal of Product Innovation Management, Vol. 12 No. 5, pp. 406-414.

Dumas, A., Whitfield, A. (1989), "Why design is difficult to manage: A survey of attitudes and practices in British industry", European Management Journal, Vol. 7 No. 1, pp. 50-56. DOI: 10.1016/0263-2373(89)90143-6

Farr, M. (1965), “Design management: Why is it needed now?", Design Journal, No. 200, pp. 38-39, available at: https://vads.ac.uk/diad/article.php?title=200\&year=1965\&art icle $=$ d.200.22 (accessed 14 October 2019).

Fernández-Mesa, A., Alegre-Vidal, J., Chiva-Gómez, R., Gutiérrez-Gracia, A. (2013), "Design management capability and product innovation in SMEs", Management Decision, Vol. 51 No. 3, pp. 547-565. DOI: 10.1108/00251741311309652

Gaynor, G.H. (2002), Innovation by design: what it takes to keep your company on the cutting edge, AMACOM, New York.

Gorb, P., Dumas, A. (1987), “Silent design”, Design Studies, Vol. 8 No. 3, pp. 150-156. DOI: $10.1016 / 0142-694 X(87) 90037-8$.

Junginger, S. (2008), "Product development as a vehicle for organizational change", Design Issues, Vol. 24 No. 1, pp. 26-35. DOI: 10.1162/desi.2008.24.1.26

Kotler, P., Rath, G.A. (1984), “Design: A Powerful but Neglected Strategic Tool”, Journal of Business Strategy, Vol. 5 No. 2, pp. 16-21. DOI: 10.1108/eb039054

Kotter, J.P. (1996), Leading change, Harvard Business School Press, Boston, MA.

Linden, A. (2017), "How I Build Effective Design Teams", available at: https://www. designerfund.com/blog/build-effective-design-teams/ (accessed 6 June 2020).

OECD (2015), Frascati Manual 2015: Guidelines for Collecting and Reporting Data on Research and Experimental Development, OECD, Paris.

Perks, H., Cooper, R., Jones, C. (2005), "Characterizing the role of design in new product development: an empirically derived taxonomy", Journal of Product Innovation Management, Vol. 22 No. 2, pp. 111-112. DOI: 10.1111/j.0737-6782.2005.00109.x

Piatier, A. (1984), Barriers to Innovation, Frances Pinter, London.

Roy, R., Riedel, J.C. (1997), "Design and innovation in successful product competition", Technovation, Vol. 17 No. 10, pp. 537-549. DOI: 10.1016/S0166-4972(97)00050-3

Rutkowski, E. (2016), "Maszyna też chce być piękna”, available at: https://mycompanypolska.pl/artykul/362/wzornictwo-design (accessed 2 June 2020).

Rutkowski, E. (2015), „Wywiad z Maciejem Głogowskim, dyrektorem ds. rozwoju firmy Flowair", available at: https://projekt-wbz.com.pl/a/48,wywiad-z-maciejemglogowskim-dyrektorem-ds-rozwoju-firmy-flowair (accessed 2 June 2020).

Teece, D.J., Pisano, G., Shuen, A. (1997), "Dynamic capabilities and strategic management”, Strategic Management Journal, Vol. 18 No. 7, pp. 509-533. DOI: 10.1002/ (SICI)1097-0266(199708)18:7<509::AID-SMJ882>3.0.CO;2-Z

Thomson, M., Koskinen, T. (Eds.) (2012), Design for Growth \& Prosperity. Report and Recommendations of the European Design Leadership Board, The European Design Leadership Board/Unigraphia, Helsinki.

Topalian, A. (1990), "Design Leadership in Business: The Role of Non-Executive Directors 
and Corporate Design Consultants", Journal of General Management, Vol. 16 No. 2 , pp. 39-62. DOI: 10.1177/030630709001600203

Verganti, R. (2011), "Radical design and technology epiphanies: a new focus for research on design management", Journal of Product Innovation Management, Vol. 28 No. 3, pp. 384-388. DOI: 10.1111/j.1540-5885.2011.00807.x

Walsh, V. (1996), "Design, Innovation and the Boundaries of the Firm", Research Policy, Vol. 25 No. 4, pp. 509-529. DOI: 10.1016/0048-7333(95)00847-0

Walsh, V., Roy, R., Bruce, M., Potter, S. (1993), "Perspectives on Design and Innovation", Creativity and Innovation Management, Vol. 2 No. 2, pp. 78-86. DOI: 10.1111/j.14678691.1993.tb00076.x

Woodham, J.M. (2010), "Formulating national design policies in the United States: recycling the emperor's new clothes", Design Issues, Vol. 26 No. 2, pp. 7-46, available at: https://www.mitpressjournals.org/doi/pdf/10.1162/DESI_a_00003 (accessed 14 October 2019). 